\title{
"The Gallery Will Be Reserved For Ladies"
}

Margaret N. Keyes

SO READ THE NOTICE PUBLISHED IN THE lowa City Daily Republican on June 27, 1856 concerning a public meeting for ratification of nominations made by the Republican National Convention at Philadelphia. ${ }^{1}$ In that same year the Journal of the House of Representatives of the State of lowa contained the following item: "And when there are no vacant seats in the Lobby, the spectators [will] be required to retire to the Gallery, unless it is already full." 2

In 1854, at the inauguration of Governor James W. Grimes in the House Chamber, the ". . . seats, lobbies and gallery were densely filled with members, privileged outsiders, great aspirants, and little aspirants . . ."3 At that time the floor of the House gallery was a cause for concern, apparently because of a shortage of spittoons, and an argument ensued in the House over the proper floor covering. "Mr. Bonson moved that the clerk be authorized to carpet the Gallery of the Hall."4 "Mr. Neal moved that the clerk be directed to cover the floor with saw-dust." ${ }^{5}$ After some discussion, a substitute motion, specifying "cheap carpet" as the covering was offered and adopted. ${ }^{6}$

These and other clues convinced current researchers of the history of lowa's First State Capitol that a gallery must have existed

\footnotetext{
${ }^{1}$ Iowa City Daily Republican, Vol. 1, Nס. 19 (June 27, 1856), p. 2.

${ }^{2}$ Journal of the House of Representatives of the Sixth General Assembly of the State of lowa [1856] (Iowa City: P. Moriarty, Printer, 1857), p. 31.

${ }^{3}$ lowa Capitol Reporter, Vol. 13, No. 26 (December 13, 1854), p. 2.

${ }^{4}$ Journal of the House of Representatives of the State of lowa [1854] (lowa City: D. A. Mahony and J. B. Dorr, Printers, 1855), p. 9.

${ }_{6}^{5} /$ bid., p. 12.

${ }^{6} /$ bid.
} 


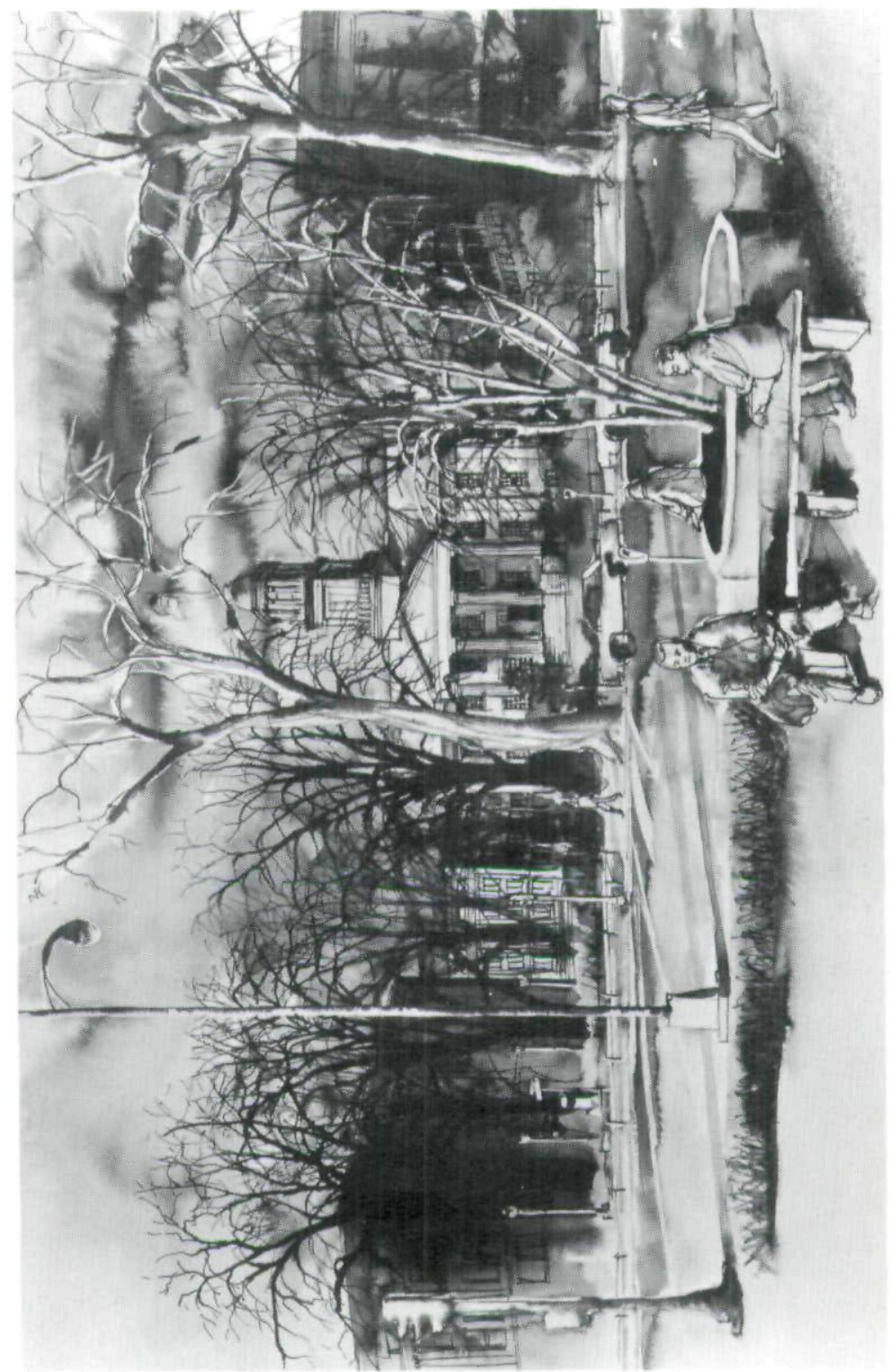

Old Capitol: East Portico view showing the building as center of The University of lowa Pentecrest. Ink wash sketch by Stan Haring. 


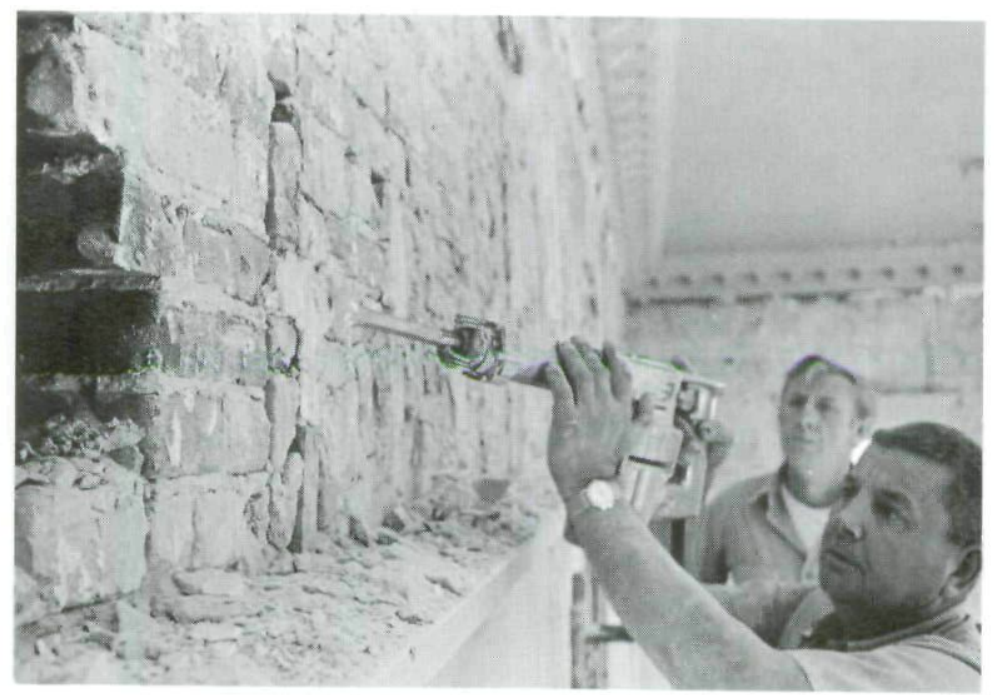

Figure 1. Dale Helfrich (foreground) and Tom Schoomer of The University of lowa Physical Plant removing plaster from the interior brick wall of the House Chamber August, 1972. Photograph by Warren M. Paris.

in the House Chamber, despite the long-held belief that, although galleries had originally been planned, they were never constructed because of the lack of money to do so. ${ }^{7}$ Further support came from an 1853 Webster dictionary which defines a gallery on the interior of a structure as ". . . a floor elevated on columns and furnished with pews or seats, usually ranged on three sides of the edifice." 8 Thus the mid-nineteenth century and the twentieth century ideas of a gallery were identical.

Conclusive evidence of the existence of the House gallery was discovered in August, 1972, when workmen began preliminary steps for the restoration of Old Capitol. As they removed plaster from the walls of the House Chamber, working meticulously by hand with chisel and hammer in the early investigative stages and later with pneumatic drill (Figure 1), the sockets in the interior stone wall

\footnotetext{
${ }^{7}$ Benjamin F. Shambaugh, The Old Stone Capitol Remembers (Iowa City: The State Historical Society of lowa, 1939), p. 105.

${ }^{8}$ Noah Webster, An American Dictionary of the English Language (Springfield, Mass.: Published by George and Charles Merriam, 1853), p. 491.
} 
which had held the large supporting beams (Figure 2) were uncovered between the first and second windows from the wall separating the chamber from the hall. Also in the interior brick wall were found bricks positioned vertically, indicating the location of additional supporting members for the floor. The gallery did exist!

Stovepipe holes, also filled with brick, revealed the position of two chimneys located near the cupola but no longer extant. An 1853 photograph of the building (Figure 3) showed the interior chimneys, but now the exact location is known. Another early picture had revealed that a wainscot with a chair rail had been a part of the interior architecture of the House Chamber (Figure 4). The discovery of wood plugs in the walls around the room at chair rail height gives the restorers its exact height and position. These clues to the original appearance of Old Capitol have been significant as architects and researchers on the project analyze fragmentary bits of documentary data in order to piece together an authentic picture of the historic building as it was during the $1842-1857$ period when it served as a capitol.

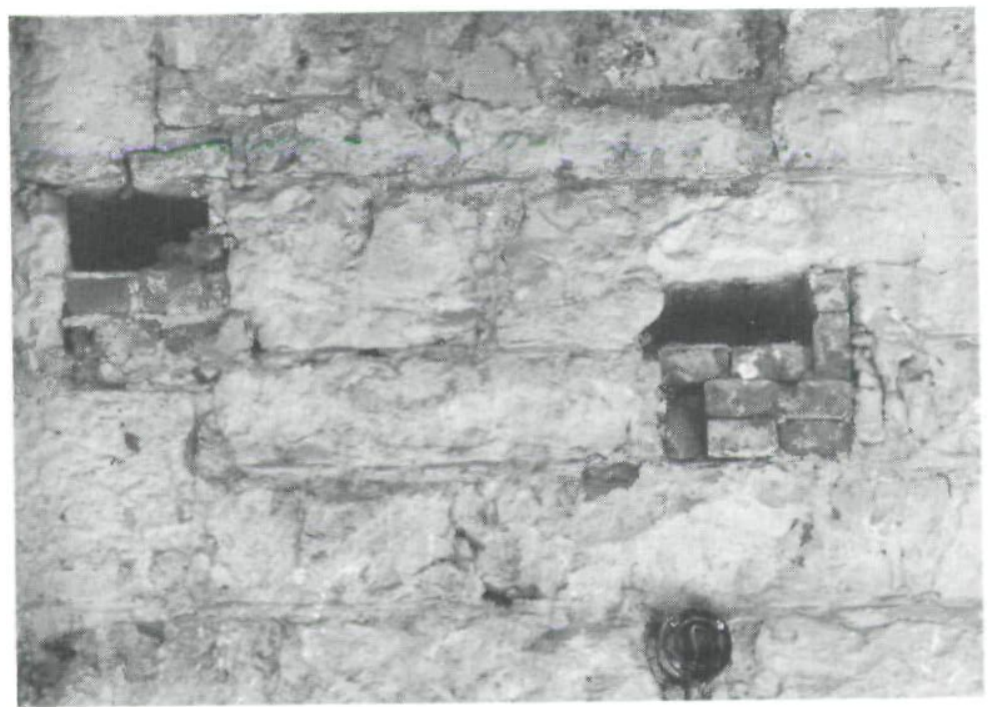

Figure 2. Brick-filled sockets in the interior stone wall indicate the positions of supporting beams for the gallery in the House Chamber. 


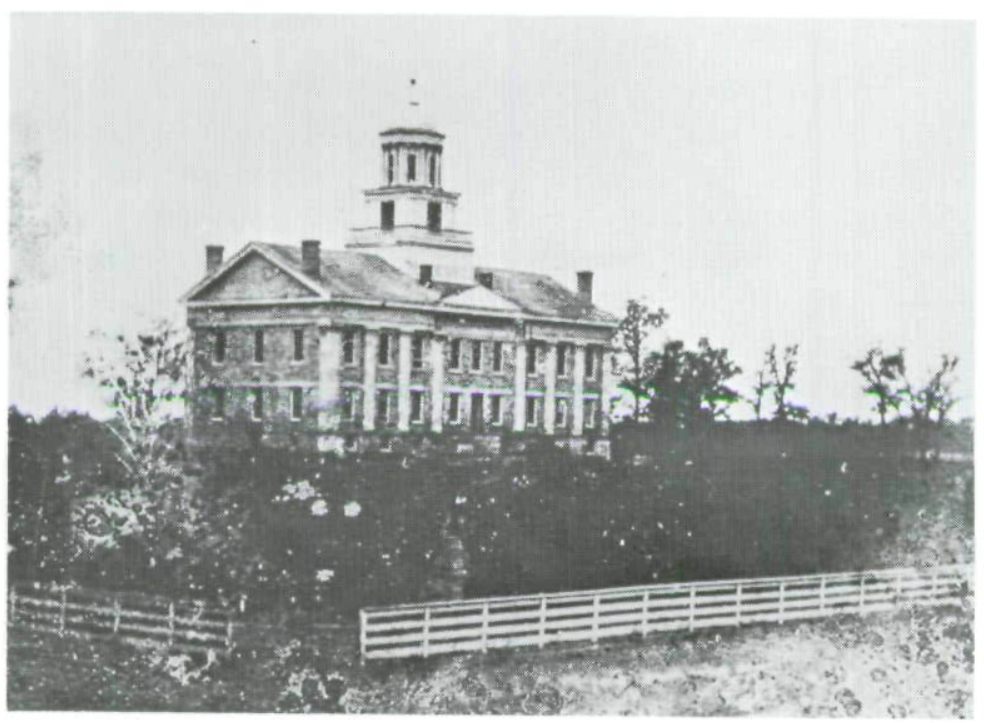

Figure 3. An 1853 picture of Old Capitol shows the chimneys that once were located near the cupola. Photograph from University Archives, University of lowa Libraries.

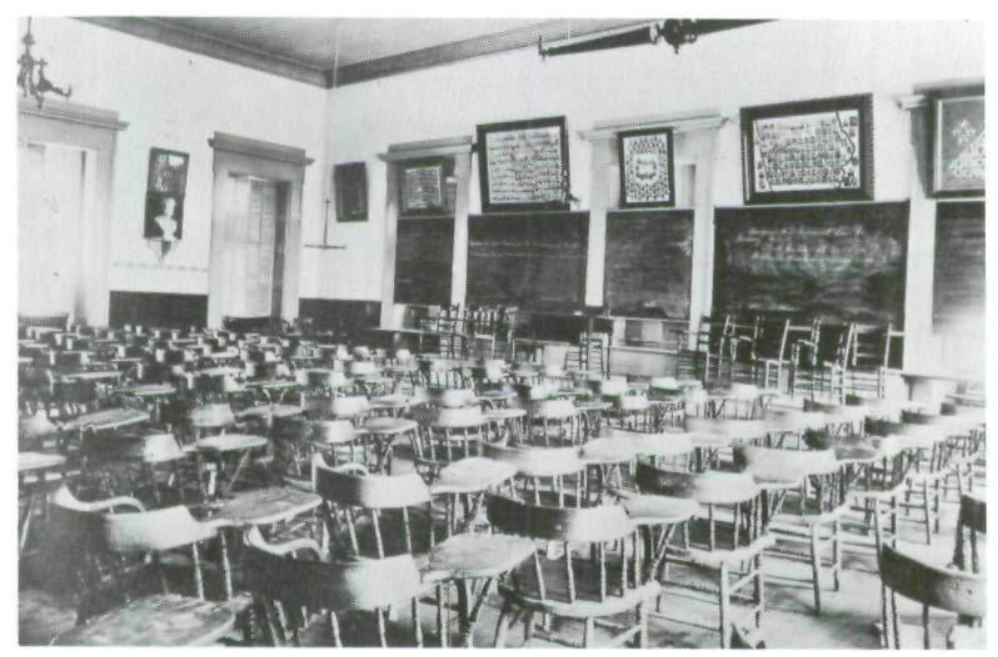

Figure 4. A Law College classroom in the House Chamber circa 1905. The original cornice and the wainscot are visible in this picture. Photograph from the 1906 issue of The Hawkeye. 


\section{Historical Background for the Restoration}

The first occupancy of the building was on December 1, 1842, by the Fifth Legislative Assembly of the Territory of lowa. It was used by the territorial government until December 28, 1846, when President James K. Polk signed the act of admission which proclaimed lowa a State of the Union. On that date the building became the capitol of the State of lowa, a distinction it held until the seat of government was moved westward to Des Moines in 1857. The act which provided for removal of the capital from lowa City also transferred the capitol building to the University of Iowa.

In Old Capitol, the third building to be the governmental headquarters, the last four lowa territorial legislatures met. In it lowa made the transition to statehood. Its first state governor, Ansel Briggs, was inaugurated there. Its first six General Assemblies met there. The constitution which remains the fundamental law of lowa was drafted in Old Capitol. The statute laws of lowa were made in the building between 1842 and 1857, and the Code of 1851 was compiled there. The University of lowa was chartered in the building by the First lowa General Assembly on February 25, 1847, just fifty-nine days after lowa's final admission to statehood. The Republican party of Iowa was founded there in $1856 .{ }^{9}$

Today Old Capitol, as the building is known by all lowans, is the focal point of the University of lowa campus and will continue to be so in the current plans for restoration of the building. The University's central administration offices remained there continuously for 113 years, until their removal in 1970, preparatory to Old Capitol's restoration as an historic site. The building has served the University in many ways in addition to administrative facilities-for classrooms and offices, for a University chapel, library, rooms for archives, alumni association, nineteenth century literary societies, and many others.

\section{The Original Plan}

John Francis Rague, a native of New Jersey who studied with the noted architect, Minard Lafever, in New York City, designed Old Capitol while he was supervising the construction of the Illinois state

\footnotetext{
${ }^{9}$ Robert T. Hilton, Old Capitol (Brochure written by Robert T. Hilton and researched by Robert T. Hilton, Steven K. Dawson, and Margaret N. Keyes, 1971).
} 
capitol in Springfield. There he had won a $\$ 200$ prize in a competition for the design of the Illinois capitol. Similarities in the design of the two Greek Revival buildings are unmistakable. Talbot Hamlin has called lowa's capitol building ". . . a simple but excellently designed building." 10

Rague came to lowa City, accompanied by William McDonald and William Skeen with whom he had formed a partnership, and supervised the early construction of Old Capitol. McDonald and Skeen served as foremen for the project. Nine days after the cornerstone was laid on July 4, 1840, Rague resigned, ostensibly because of the inferior quality of the stone which was available and also because of lack of funds to complete the building according to his original plans. Work was continued under the supervision of Chauncey Swan and, later, by William B. Snyder, Morgan Reno, Joseph T. Fales, and William Pattee. Subsequently, Rague designed buildings which are still extant in Dubuque, lowa, and in Madison and Milwaukee, Wisconsin.

Old Capitol is rectangular and measures 120 feet in length and 60 feet in width. It is constructed of the Coralville member of the Cedar Valley limestone of the Devonian period. The dominant color of this stone is a tannish-gray. The steps leading to the platforms of the porticoes are of granite. The porticoes, the main cornice, and the cupola are of wood. The four fluted columns on each of the porticoes are of the Doric order and are constructed of wood which has been sandblasted.

In her study of Rague's work, Betsy Woodman describes the exterior of Old Capitol as follows:

The height of the building from the ground line to the ridgepole of the roof measures 60 feet. North and south tetrastyle porticoes project 12 feet from the long sides. A raised basement elevates the upper two stories over six feet above the ground level. Pilasters appear on the main facades oniy; thus, a peristyle temple treatment does not carry around the building. A cupola rises from the center of the roof, beginning with two square bases. Its height is 54 feet from the base to the top of the cupola. The second one atop the first is smaller in size so that a graduated series of sections results. The lower square structure is trimmed with a balustrade and the one above with a heavy cornice and pilasters at the corners. The octagonal lantern encircled by 16 engaged Corinthian columns and punctured by a window in

${ }^{10}$ Talbot Hamlin, Greek Revival Architecture in America (New York: Oxford University Press, 1944), p. 255. 
each facet of the octagon is capped with a ribbed dome. ${ }^{11}$

The exterior as it presently exists is changed little, if any, from the original intent of the architect. The only major change on the outside is the addition in the 1920s of the west portico which is identical to the east one. A photograph of the west side of Old Capitol, taken in 1920, gives structural evidence that Rague had planned for the construction of porticoes on both the east and the west sides (Figure 5). A major remodeling and rehabilitation of the building took place between 1921 and 1924 when a steel structure was installed and the building was fireproofed. Recognition of the structure's architectural merit is evident in the limitation on reconstruction set by a legislative act in 1917 while the project was in its formative stages:

Sec. 3. Limitation on reconstruction. That in the reconstruction of said building, the exterior shall not be changed in its appearance, structure or design and only such change shall be made in the interior of said building as is necessary to properly carry out the purpose and intent of this act to make said building fireproof or substantially so and to reproduce said structure without change in any of its original parts. ${ }^{12}$

To date, Rague's original floor plans for Old Capitol have not been located. However, they were described as follows in an 1840 Journal:

. . the basement story is entered by two doors in the opposite ends, both opening into a hall seven feet wide, which runs directly through the building north and south, dividing it into two equal parts. There are four rooms on each side about twenty feet square, designed for committee rooms. There is also a large and convenient woodroom, and a fire-proof vault, arched with brick, and covered with grouted masonry, more than three feet thick, for the safety of public documents. On the next floor there is the same division north and south, and a broad hall or vestibule east and west, entered from the porticos on each side of the building. North of the vestibule, east side, is a room forty-three by twenty-two and a half feet, designed for the supreme court; a corresponding room of the same size on the south of the vestibule, is designed for the use of the Secretary of the Territory. West of the north and south hall are four rooms, equal in size,

${ }^{11}$ Betsy H. Woodman, John Francis Rague: Mid-Nineteenth Century Revivalist Architect (Unpublished master's thesis, The University of lowa, 1969), pp. 72-73.

${ }^{12}$ Report of the Special Committee of the State Board of Education, Showing the expenditure of the $\$ 50,000.00$ appropriation made by the 37 th General Assembly for the Repair and Fireproofing of the Old Capitol, July 3, 1923, N. P. 


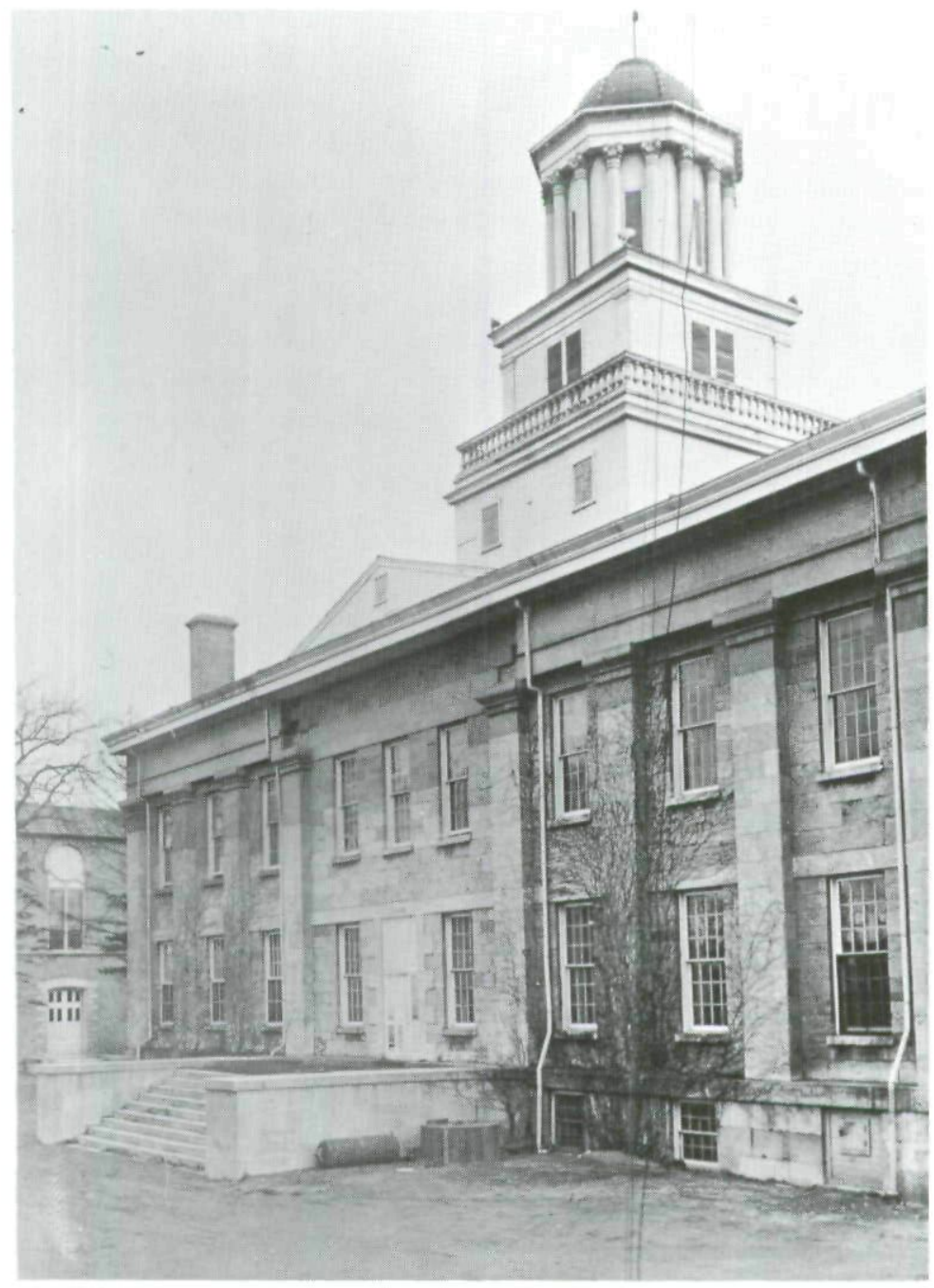

Figure 5. The west side of Old Capitol in 1920, showing the original recessed cornice area and the platform planned as a part of the portico. Photograph by Fred W. Kent. 
designed for the use of the Governor, Auditor, Treasurer, and the Library. On the upper floor the north and south hall is omitted. In the south wing is the Representatives hall, fifty-two by forty-three feet in the clear. In the north wing are the Council chamber and three small committee rooms, cut off from the west of it. ${ }^{13}$

Such a description leaves unanswered questions. Were the four rooms on the west side of the floor above the basement listed from left to right? Was the Governor's office in the southwest corner of the building and the Library in the northwest? Were the three small committee rooms which were planned to adjoin the Council (Senate) Chamber ever constructed? Today there is no visible evidence that they were.

Additional documentation must be located to answer such questions. Failing this, assumptions or "educated guesses" must be made in order to arrive at a satisfactory and logical solution for the floor plan of Old Capitol. Based upon the 1840 description above, the floor plans for the restored building have been developed.

The hall or vestibule is centered with a reverse spiral staircase which connects the first and second floors. Originally, the first floor and the basement were connected by a straight staircase, immediately below the spiral staircase, which extended from the north on the first floor to the south at the basement level. In the 1920 s remodeling, the straight staircase was replaced with a spiral staircase which complements the original design, and the original spiral was completely rebuilt but was copied from the prototype. Only two visible changes were made from the early staircase (Figure 6). The south (or left) newel post was ten inches higher than the north one, apparently because the craftsmen constructing it were unable to cope with the fast descent of the inside rail and maintain the posts at an even height. The 1920s designers were able to solve this problem, and today's staircase has newel posts of the same height. The underside of the original stairs was ribbed, as Figure 6 shows. This feature will be replaced in the present restoration.

The interior of the building has changed considerably from the original floor plan in order to adapt the structure to the needs of The University of lowa. The restoration will return it to the original plan wherever this is practicable.

13 Journal of the House of Representatives of the Third Legislative Assembly of the Territory of lowa [1840] (Dubuque: Wm. W. Coriell, Printer, 1841), pp. 191-192. 


\section{Restoration Plans}

As voted by the Old Capitol Restoration Committee, the plans call for preserving the total history of Old Capitol. When implemented, this recommendation will mirror the four years the building served as territorial capitol, the eleven years as state capitol, and the

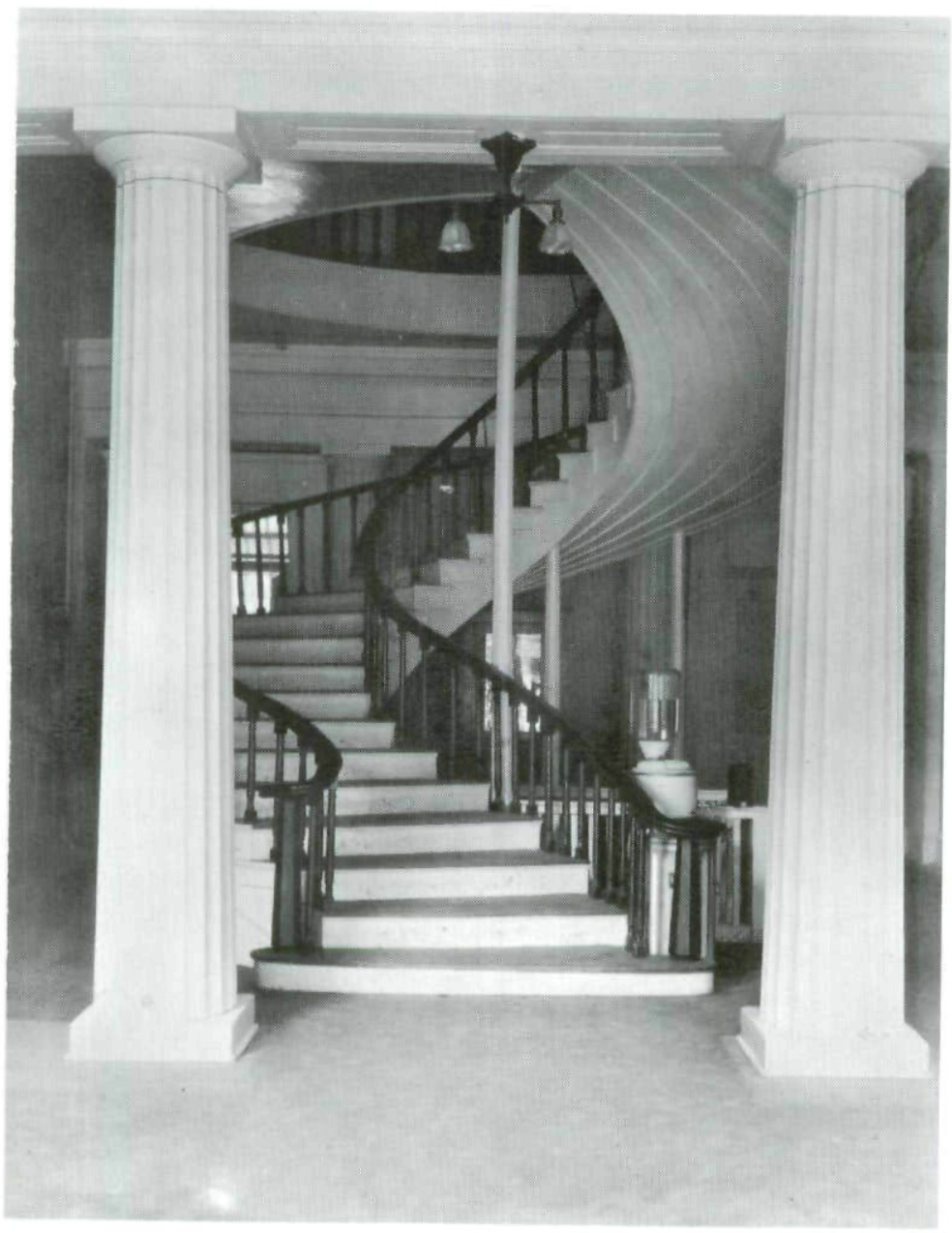

Figure 6. The original staircase which was replaced in the 1920's. Photograph by Fred W. Kent. 
116 years as central building of The University of Iowa.

The House Chamber, Supreme Court Chamber, Governor's, Auditor's, and Treasurer's offices, and the Library will be restored to territorial and statehood days. The Senate Chamber and the President's office and reception area (originally the office of the Secretary of the Territory) will represent University history in the building and depict the 1920s remodeling. The reception area adjacent to the President's office will serve as a business and reception room for the restored museum. Since the ground floor continues to be occupied by University offices, no decisions have been made concerning its use. Long-range plans call for restoration of the basement as well as for consideration of the landscaping of the building.

\section{Furnishings for Old Capitol}

The restoration committee is searching for information concerning furniture and accessories which were originally in Old Capitol between 1842 and 1857. Also, appropriate furniture for a legislative building of the time period is being sought, particularly items which reflect the cultural heritage of frontier lowa.

To date, one chair (Figure 7) has been located which is thought to have been in Old Capitol in the 1840s. Made of black walnut and having a caned seat and chair back, it may well be one of "26 cane chairs" which were purchased from a St. Louis firm in $1839 .^{14}$ Evidence exists that furniture used in the First Territorial Capitol in Burlington between 1838 and 1842 was transported by wagon to lowa City in 1842 for use there. As late as 1848 , however, some of the early furniture was still in Burlington since at least two officials refused to move to lowa City, but another record shows that it was moved to the new capitol in that year. ${ }^{15}$

The chair, which was found several years ago in a room in Old Capitol by Willard L. Boyd, President of the University of Iowa, may well be one of the original 26 since its design and construction are of the 1830-1840 vintage. In addition, there were 26 representatives in the Legislative Assembly (House) at the time the cane chairs were

${ }^{14}$ Legislative and Contingent Expenses of the Territory of lowa, Account No. 80,345 (National Archives, Washington, D.C.), N.P.

${ }^{15}$ Acts, Resolutions and Memorials Passed at the Extra Session of the First General Assembly of the State of lowa [1848] (Iowa City: A. H. Palmer, Printer, 1848), p. 81. 
purchased, leading researchers to think that the existing cane chair is the prototype for the ones used in that chamber. In order to present an authentic picture of the House Chamber of the restoration period, reproductions of the chair illustrated will be made.

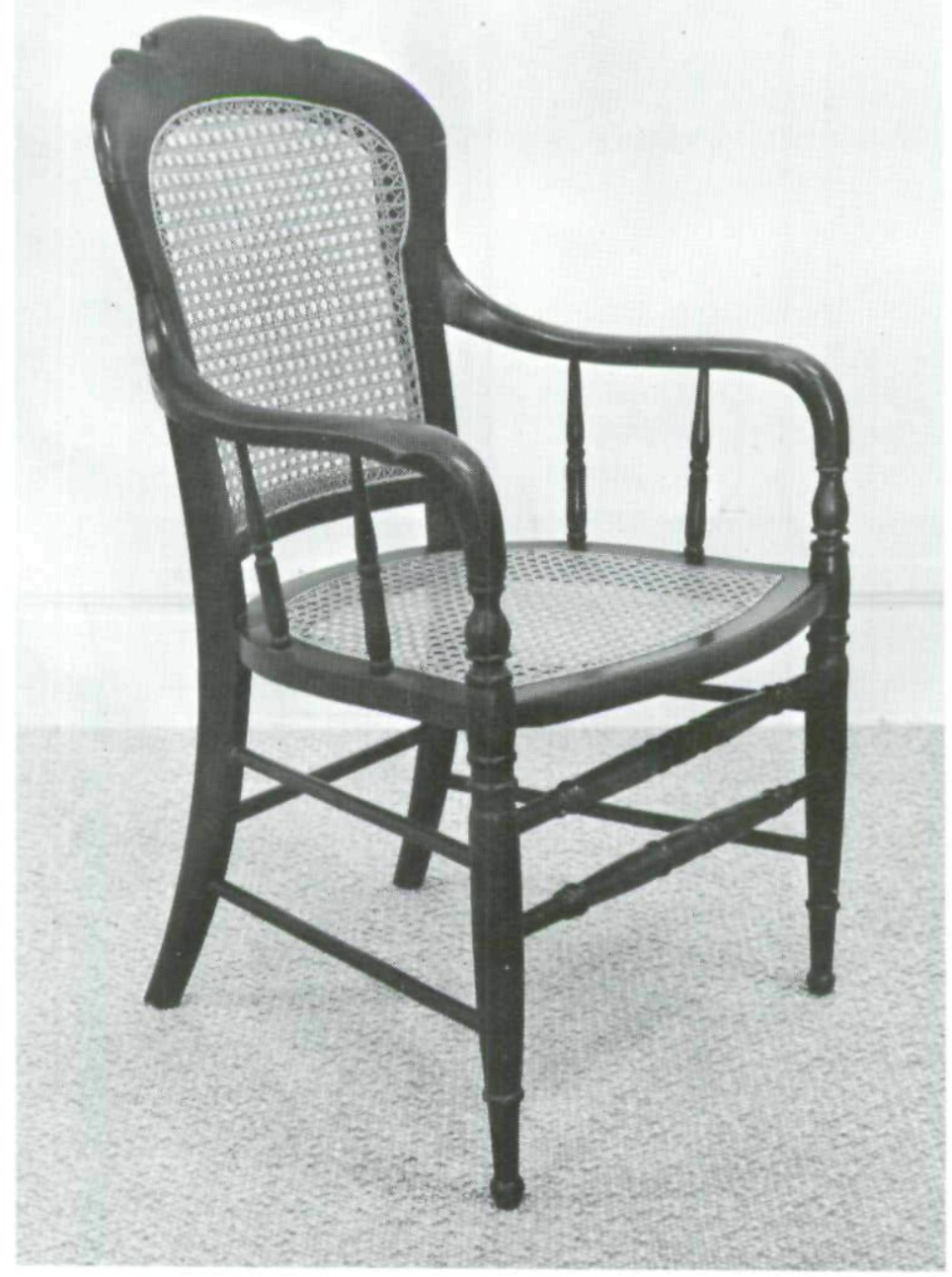

Figure 7. Walnut armchair with cane seat and back, thought to have been in the original House Chamber. 
Several lowa pieces have been obtained for use in the restored building. A native lowa black walnut secretary (Figure 8), made in Scott County circa 1840 , was the first major gift to the Committee in June, 1972. Other recent gifts include a cherry drop-leaf table, a pine pedestal table, a camphene desk lamp, several cast-iron spindles, books, and maps.

Of special interest to research scholars will be the restored Library and its collection of rare books. Early catalogues of acquisitions for the Territorial-State Library have been located, and efforts are being made to secure the

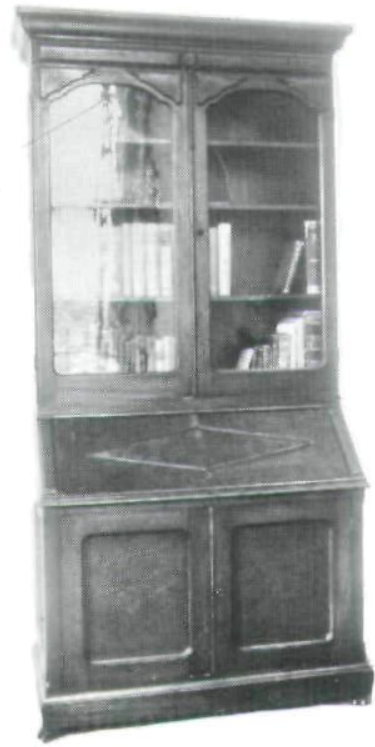

Figure 8. Walnut secretary made in Scott County circa 1840.

volumes listed. ${ }^{16}$ Mrs. Martha Esbin, research librarian, is coordinating this phase of the restoration project, and she has located several books which were in the early library.

\section{Carver Gift Initiates Funding}

Funding for the project is being obtained from several sources. The initial gift was for the restoration of the House Chamber, a designated part of the $\$ 3.5$ million gift to the University in November, 1971, by Mr. and Mrs. Roy L. Carver, Muscatine. A $\$ 313,660$ grant from the U.S. Department of Housing and Urban Development under the Open Spaces Program has been received.

Currently, a statewide campaign for funds from private sources is in progress by a sub-committee co-chaired by Darrell D. Wyrick,

${ }^{16}$ Johnson Brigham, "Pioneer History of the Territorial and State Library of lowa, II," Annals of lowa (3rd Series), Vol. X, No. 8 (January, 1913), pp. 590-628, contains the "Catalogue of Territorial Library Made by Librarian [Theodore S.] Parvin in 1839." A second source is: Catalogue of the lowa Territorial Library (lowa City: Printed by A. F. Wood, 1845, and compiled by Morgan Reno, Librarian). 
Executive Director, The University of Iowa Foundation, and Joseph W. Meyer, Executive Director, The University of lowa Alumni Association. Gifts in kind, including furniture, accessories, books, and maps, are being accepted in addition to financial assistance.

The restoration of Old Capitol was initially proposed by President Boyd in July of 1970. A national committee, including alumni of the University, non-alumni, legislators, and students, faculty, and staff members of the University, was appointed under the chairmanship of Mrs. Virgil M. Hancher, widow of a long-time president of the University. Mr. Frank T. Nye, associate editor of the Cedar Rapids Gazette, is Vice-Chairman of the Committee.

University architect, George L. Horner, is serving as architect for the project and is being assisted by Ferry and Henderson Architects, Inc., of Springfield, Illinois, as consultants in the House Chamber phase of the project. The Illinois firm was in charge of the restoration of the Illinois Old Capitol, which also was designed by John F. Rague and is of the same period.

Research for the project is directed by Margaret N. Keyes of the University of lowa Department of Home Economics who is on appointment as a University of Iowa Foundation Research Professor. Several University of lowa students have been assisting her with research for the restoration. Four graduate students have held research assistantships in connection with the project: Ann M. Baker, Davenport; Leslie Bohnenkamp, West Point; Steven K. Dawson, Corwith; and Christine M. Piotrowski, Niles, Illinois. As a part of his study for the Master of Arts degree, Dawson completed a thesis on the history of the House Chamber and made the initial projection for its restored interior architecture and furnishing. ${ }^{17}$ Other students who have contributed to the search for information concerning the history of Old Capitol are Condra Sue Easley, Mason City; Candice Goodrich Elliott, Mount Vernon; and David W. Wright, Decorah, who conducted investigations as a part of directed individual study courses while university seniors.

In addition to Mrs. Hancher, Mr. Nye, Mr. Horner, Mr. Meyer, Mr. Wyrick, and Miss Keyes, the following are members of the Old Capitol Restoration Committee: Philip D. Adler, Davenport; Robert

\footnotetext{
${ }^{17}$ Steven K. Dawson, The Interior Design of the House of Representatives Chamber of lowa's Old Capitol 1842-1857 (Unpublished master's thesis, The University of Iowa, 1972).
} 
L. Alexander, Iowa City; Walter A. Anneberg, Carroll; Barbara Avery, Spencer; Ann Baker, Davenport; Mrs. Charles Bendixen, Bettendorf; President and Mrs. Willard L. Boyd, lowa City; Francis Braley, Shenandoah; Edward Breen, Fort Dodge; Donald Burington, Mason City; Mrs. Shannon B. Charlton, Manchester; W. Charlene Conklin, Waterloo; David Dancer, Des Moines; W. E. Darrington, Sr., Persia; Steven K. Dawson, Minneapolis; Candice G. Elliott, Minneapolis; Edwin B. Green, lowa City; Mrs. Ralph U. Heninger, Davenport; Robert T. Hilton, Iowa City; H. Clark Houghton, Iowa City; Richard Kautz, Muscatine; Fred W. Kent, Iowa City; Clifton C. Lamborn, Maquoketa; E. F. Lindquist, lowa City; Kenneth MacDonald, Des Moines; Governor Robert D. Ray, Des Moines; Jonathan Richards, Red Oak; Fred Schwengel, Davenport; Mrs. James A. Van Allen, Iowa City; Percie Van Alstine, Gilmore City; William J. Wagner, Des Moines; Mrs. William B. Waterman, Davenport; Floyd F. Whitmore, Corning; and David W. Wright, Decorah.

The scheduled completion date for the restoration of Old Capitol is 1976 as The University of Iowa's contribution to the National Bicentennial. The restoration of the building as a living museum where meetings, lectures, and concerts will continue to be held, where library holdings will be used for research study, and where daily guided tours of the building will be available, will, in effect, return Old Capitol to the people of the state and will commemorate lowa's political, legal, and educational history inherent in the edifice. 
Copyright of Annals of Iowa is the property of State of Iowa, by \& through the State Historical Society of Iowa and its content may not be copied or emailed to multiple sites or posted to a listserv without the copyright holder's express written permission. However, users may print, download, or email articles for individual use. 